I 119

\title{
中小規模事業場における産業保健活動に関する調査 一従業員の意識及び保健行動についてー
}

長崎 真知子 1 、高橋 法人 ${ }^{1}$ 、藤野 昭宏 ${ }^{1}$

${ }^{1}$ 産業医科大学 医学部 医学概論教室

【はじめに]専属産業医の選任が義務付けられていない中小規模事業場における産業保健活動に関する調查は、 これまで事業主及び産業医に対して実施されることがほとんどであった。今回、産業保健サービスの受け手 である従業員の方の意識・行動調査することによって、中小規模事業場における産業保健活動の現状と今後 のあり方について検討した。

【方法】啒託産業医によって労働者の健康管理等が行われている中小規模事業場 (S 市、製造業) 8社の従業 員を対象に自記式アンケートを配布し、回答を得た $(n=661)$ 。アンケートの内容は主に、産業保健活動（産 業医及び事業場外施設等) の認知について、健診後の保健行動等である。

【結果】1）<産業保健活動の認知〉「産業医という言葉をご存知ですか」という質問に対して、「くく知つ ている」または「少しは知っている」という回答が $79.1 \%(n=523)$ であった。そのうち、産業医の具体的 な職務内容に関する質問（複数回答可）に対しては、健康診断と回答したものが $20.3 \%(n=269)$ 、健康相談 が 27.8\%（n=369）、健康教育が 17.8\%（ $n=236) 、$ 職場巡視が $22.4 \% （ n=298) 、$ 外来診療が $11.7 \%(n=156)$ という結果であった。2）<従業員自身の健康管理対策＞健康診断後に要再検查の結果を受け取った場合の 保健行動については、自宅や職場付近の医院（かかりつけ医）に相談する」と回答したものが $61.9 \%(\mathrm{n}=358)$ と「産業医または産業保健師に相談する」との回答の $23.2 \%(\mathrm{n}=134)$ を上回った。

【考察】今回調查を行った中小規模事業場においては、予想以上に産業医に関する認知度は高かった。しかし ながら、産業医の職務内容に関しては必ずしも本来業務については広く認知されているとは限らないと考え られた。一方、従業員自身の健康管理対策に関しては、健康診断後の保健行動としてかかりつけ医に相談す る割合が高く、常態䡃務ではない啒託産業医活動の限界を示しているものと考えられた。医師会を始めとす る地域医療と産業保健活動との密な連势が中小規模事業場で働く従業員にとってより一層重要になるものと 思われる。

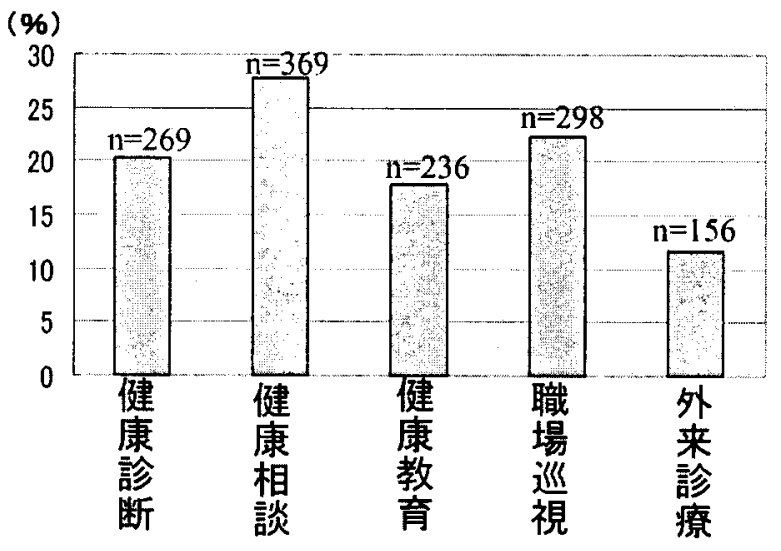

図1. 産業医の職務内容の認知

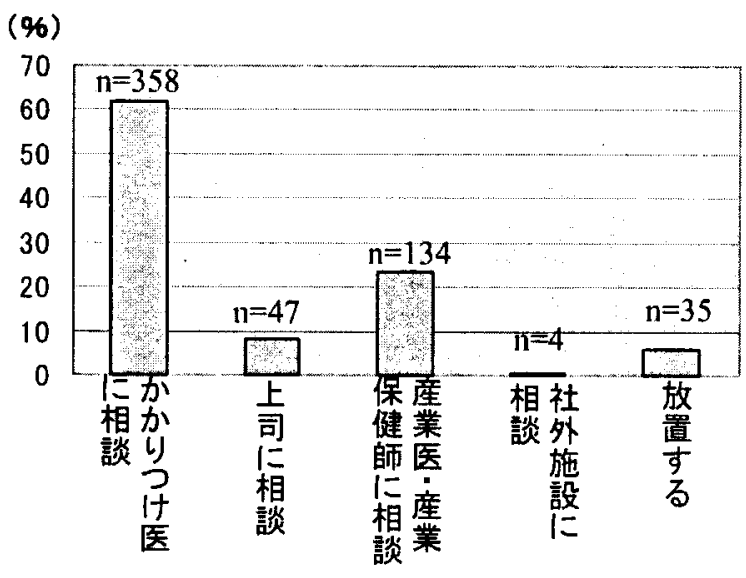

図2. 健診後の保健行動 